\title{
Profile of Diarrheal Patients Aged Less than Five Years Old Hospitalized in Dr. Soetomo General Hospital Surabaya in 2016-2018
}

\author{
Nathanael Jordan ${ }^{1}$, I Gusti Made Reza Gunadi Ranuh ${ }^{2}$, Gadis Meinar Sari ${ }^{3}$
}

${ }^{1}$ Faculty of Medicine, Universitas Airlangga, Surabaya, Indonesia.

${ }^{2}$ Department of Pediatrics, Faculty of Medicine, Universitas Airlangga, Surabaya, Indonesia.

${ }^{3}$ Department of Physiology, Faculty of Medicine, Universitas Airlangga, Surabaya, Indonesia.

\section{A B S T R A C T}

Introduction: Diarrhea is a collection of symptoms in the form of decreased stool consistency accompanied by more than normal frequency of defecation. Diarrhea is the second largest cause of death in children under five years old. In 2010, East Java was ranked first in the frequency of outbreaks in Indonesia. This study described the profile of diarrhea patients in children less than 5 years old in the Children's Ward of Dr. Soetomo General Hospital Surabaya in 2016-2018. Dr. Soetomo General Hospital Surabaya was chosen for data collection because it is one of the main referral hospitals in Indonesia, thus it has diverse cases. This study aimed to describe the profile of diarrhea patients in children less than 5 years old in the Children's Ward of Dr. Soetomo General Hospital Surabaya in 2016-2018.

Methods: This study was a retrospective study by assessing the patient's medical record and analyzed descriptively.

Results: There were 650 patients (425 male and 225 female), at most $6-11$ months $(34.6 \%)$. Most patients were classified as malnourished (45.4\%). The type of diarrhea was dominated by acute watery diarrhea (94.8\%). Mild-to-moderate dehydration $(84.2 \%)$ was found in most patients. The comorbidities were found in $83.4 \%$ of patients, with malnutrition $(45.4 \%)$ and febrile seizures $(30.3 \%)$ as the most common contributors. The therapy used was intravenous rehydration (99.7\%), antibiotics (45.7\%), zinc (98.2\%), and probiotics (96.3\%).

Conclusion: Most diarrhea patients in this study were male, aged 6-11 months, mild-to-moderate dehydration, malnourished, suffering from acute water diarrhea, accompanied by comorbidities, and treated with intravenous rehydration.

(c) 2020 JUXTA: Jurnal IImiah Mahasiswa Kedokteran Universitas Airlangga. Available at https://e-journal.unair.ac.id/juxta

\footnotetext{
*Correspondence: rezagunadi@gmail.com

JUXTA: Jurnal IImiah Mahasiswa Kedokteran Universitas Airlangga p-ISSN: 1907-3623; e-ISSN: 2684-9453

DOI: $10.20473 /$ juxta.V11I22020.45-50
}

Open access under Creative Commons Attribution-ShareAlike 4.0 International License (CC-BY-SA)

\section{ARTICLE INFO}

\author{
Article history: \\ Received 9 June 2020 \\ Received in revised form 3 July \\ 2020
}

Accepted 9 July 2020

\section{Keywords: \\ Profile, \\ Diarrhea, \\ Children.}




\section{Introduction}

Diarrhea is a collection of symptoms in the form of decreased stool consistency accompanied by more than normal defecation frequency caused by infections of the digestive tract that can be caused by various organisms such as parasites, viruses, and bacteria. Diarrhea is the second largest cause of death in children under five years old. Annually, diarrhea causes 525,000 deaths among 1.7 billion cases of diarrhea in children under five years old. ${ }^{1}$ Diarrhea is an endemic disease in Indonesia that has the potential to become an extraordinary event and often causes death of children. According to the 2007 Riskesdas report, diarrhea is the first cause of death in infants (31.4\%) and toddlers $(25.2 \%)$, whereas overall, diarrhea is the fourth largest cause of death in Indonesia. ${ }^{2}$ The incidence of diarrhea is spread in all age groups with the highest prevalence in children under five years old (less than 5 years old) of $16.7 \% .^{3}$ In 2010 , East Java ranked first in the frequency of outbreaks in Indonesia. The number of diarrhea outbreak patients in 2012 decreased significantly compared to the previous year. Even so, the case fatality rate (CFR) of diarrhea from 2011 to 2012 increased to $1.45 \%$. Extraordinary events CFR target set by Indonesian Ministry of Health is expected to be less than $1 \%$, thus it can be concluded that Indonesia has not yet reached the target. Diarrhea has three types of clinical manifestations, namely acute watery diarrhea, acute bloody diarrhea (dysentery), and persistent diarrhea if it persists for at least 14 days. $^{2}$

Although oral rehydration therapy (ORT) is one of the main therapy for patients with diarrhea, morbidity and mortality rates due to diarrhea have not changed. This proves that dehydration is not the only major problem experienced in diarrhea patients. Diarrhea needs to be treated properly to prevent complications and death of children. ${ }^{4}$

In this study, we describe the profile of diarrhea sufferers in children under 5 years old who were treated in the Children's Ward of Dr. Soetomo General Hospital Surabaya in 2016-2018. Dr. Soetomo General Hospital Surabaya was chosen as a place for data collection because it is one of the main referral hospitals in Indonesia. This study was conducted to describe the profile of children under five years old who were diagnosed with diarrhea, thus it is expected to reduce the occurrence of diarrhea in children under 5 years old in the future.

\section{Methods}

This study was a descriptive study. The data for this study were taken from the central medical record at Dr. Soetomo General Hospital Surabaya, Indonesia. This study used total sampling method, which made all medical records at Dr. Soetomo General Surabaya that fulfill the inclusion and exclusion criteria eligible to be a sample. The inclusion criteria for this study were medical records of children under five years old with diarrhea and hospitalized in the Children's Ward of Dr. Soetomo General Hospital
Surabaya in 2016-2018 which contained the data needed for this study, such as sex, age, type of diarrhea, nutritional status, degree of dehydration, comorbidities, and therapy. The exclusion criteria for this study were the medical records of patients with gastrointestinal symptoms but not diagnosed as a diarrhea, such as melena and hematochezia.

The instruments used in this study were stationery, data collection sheets, and statistical data processing application (IBM SPSS Statistics 25). Data from medical records were collected through data collection sheets. The collected data was processed by moving the data from the data collection sheet to the IBM SPSS Statistics 25, then we matched the weight and age data with the z-score graph of body weight-for-age published by $\mathrm{WHO}$ and then the data was entered in to IBM SPSS Statistics 25. Comorbidities first categorized based on the presence or absence of comorbidities. If there were comorbidities, it was included in IBM SPSS Statistics 25 to be calculated, then presented in a table. After all the data was collected and processed, we presented the data in tables and diagrams.

\section{Results}

The number of patients diagnosed with diarrhea in the Children's Ward of Dr. Soetomo General Hospital Surabaya in 2016-2018 was 777 patients. After putting the inclusion and exclusion criteria into consideration, 650 patients' data matched the criteria and could be used as a research sample. A total of 127 patients' data was excluded in this study, with 12 patients diagnosed as not having diarrhea and 115 patients did not have the data needed for this study.

\section{Child Factors}

Table 1. Distribution of child factors of diarrhea patients aged less than 5 years old and hospitalized in Children's Ward of Dr. Soetomo General Hospital Surabaya in 20162018.

\begin{tabular}{llcc}
\hline \multicolumn{1}{c}{ Child Factors } & n & $\%$ \\
\hline Age & & & \\
0-5 months & 115 & 17.7 \\
6-11 months & 225 & 34.6 \\
12-17 months & 119 & 18.3 \\
18-23 months & 77 & 11.8 \\
24-29 months & 39 & 6.0 \\
30-35 months & 33 & 5.1 \\
36-41 months & 21 & 3.2 \\
42-47 months & 7 & 1.1 \\
48-53 months & 9 & 1.4 \\
54-59 months & 5 & 0.8 \\
Sex & & \\
$\quad$ Male & 425 & 65.4 \\
$\quad$ Female & 225 & 34.6 \\
Nutritional Status & & \\
\hline
\end{tabular}


No undernourishment

$294 \quad 45.2$

Undernourished

$61 \quad 9.4$

Severely undernourished

$295 \quad 45.4$

The highest incidence of diarrhea in this study was in the 6-11 months age group with a percentage of $34.6 \%$. Diarrhea sufferers of children aged less than 5 years old were mostly male, as many as $425(65.4 \%)$. The sex ratio of male and female sufferers in this study was 1.89: 1 . The nutritional status of most sufferers was severely undernourished, as much as $45.4 \%$.

\section{Clinical Characteristics}

Table 2. Distribution of clinical characteristics of diarrhea patients aged less than 5 years old and hospitalized in Children's Ward of Dr. Soetomo General Hospital Surabaya in 2016-2018.

\begin{tabular}{lcc}
\hline Clinical Characteristics & $\mathbf{n}$ & $\%$ \\
\hline Type of Diarrhea & & \\
Acute watery diarrhea & 616 & 94.8 \\
Acute bloody diarrhea & 7 & 1.1 \\
Persistent diarrhea & 27 & 4.2 \\
Degree of Dehydration & & \\
$\quad$ Diarrhea without dehydration & 44 & 6.8 \\
$\quad$ Diarrhea with mild-to-moderate & 547 & 84.2 \\
$\quad \begin{array}{l}\text { dehydration } \\
\quad \text { Diarrhea with severe dehydration }\end{array}$ & 59 & 9.1 \\
Comorbidities & & \\
$\quad$ Present & 542 & 83.4 \\
$\quad$ Absent & 108 & 16.6 \\
\hline
\end{tabular}

In this study, the type of diarrhea was mostly acute watery diarrhea $(94.8 \%)$, diarrhea with mild-to-moderate dehydration (84.2\%), and diarrhea with comorbidity present (83.4\%).

\section{Comorbidities}

Table 3. Distribution of comorbidities of diarrhea patients aged less than 5 years old and hospitalized in Children's Ward of Dr. Soetomo General Hospital Surabaya in 20162018.

\begin{tabular}{lcc}
\hline \multicolumn{1}{c}{ Comorbidities } & n & $\%$ \\
\hline Severe undernourishment & 295 & 45.4 \\
Febrile seizure & 197 & 30.3 \\
Malignancy & 93 & 14.3 \\
Anemia & 67 & 10.3 \\
Undernourishment & 61 & 9.4 \\
Pneumonia & 53 & 8.2 \\
Encephalopathy & 27 & 4.2 \\
Sepsis & 13 & 2.0 \\
Acute pharyngitis & 12 & 1.8 \\
Hirschsprung disease & 8 & 1.2 \\
Paralytic lleus & 8 & 1.2 \\
HIV & 4 & 0.6
\end{tabular}

Comorbidities of diarrhea in this study was mostly in the form of malnutrition in 295 cases (45.4\%), followed by febrile seizures in 197 cases (30.3\%), malignancy in 93 cases $(14.3 \%)$, anemia in 67 cases $(10.3 \%)$, malnutrition in 61 cases $(9.4 \%)$, and pneumonia in 53 cases $(8.2 \%)$.

\section{Therapy}

Table 4. Distribution of therapy of diarrhea patients aged less than 5 years old and hopitalized in Children's Ward of Dr. Soetomo General Hospital Surabaya in 2016-2018.

\begin{tabular}{lcc}
\hline \multicolumn{1}{c}{ Therapy } & $\mathbf{n}$ & $\%$ \\
\hline $\begin{array}{c}\text { Intravenous rehydration therapy } \\
\text { Yes }\end{array}$ & 648 & 99.7 \\
No & 2 & 0.3 \\
Antibiotics & & \\
Yes & 297 & 45.7 \\
No & 353 & 54.3 \\
Zinc & & \\
Yes & 638 & 98.2 \\
No & 12 & 1.8 \\
Probiotics & & \\
Yes & 626 & 96.3 \\
No & 24 & 3.7 \\
\hline
\end{tabular}

In this study, 648 (99.7\%) patients were given intravenous rehydration therapy, 297 (45.7\%) patients were given antibiotic therapy, $638(98.2 \%)$ patients were given zinc, and 626 (96.3\%) sufferers were given probiotics.

\section{Discussion}

The incidence of diarrhea in this study was found mostly in the 6-11 month age group, followed by the 12-17 month age group, and the 0-5 month age group. The least diarrhea rate was found in the 54-59 months age group. The results of this study are in line with the results of a morbidity survey conducted by Indonesian Ministry of Health. ${ }^{3}$ In the study, from 194 patients, the most cases of diarrhea were found at 6-11 months age group (21.65\%), followed by the $12-17$ month age group (14.43\%), and at least in the 54-59 months age group. This study even has similar results to the study conducted by Yusuf (2011) of diarrhea patients in the inpatient room of the children's health science department of Dr. Zainoel Abidin Regional Hospital in Banda Aceh; the most cases of diarrhea occurred in children aged less than 2 years old, followed by the age group of 2-5 years old, and least occurred in the age group above 5 years old. ${ }^{5}$ The same result can also be found in the research of Maryanti, et al. (2014), where the most common cases of diarrhea occurred in children in the age group of less than 3 years old, and followed by the age group of 3 to 5 years old. ${ }^{6}$ The results of the Basic Health Research conducted by Indonesian Ministry of Health (2013b) also showed results that are consistent with this study, that the most common diarrhea occurred in children in the age group of 12 to 23 months old. ${ }^{7}$ Research conducted in Ethiopia by Getachew, et al. (2018) has slightly different results from this study. In the study, the cases were more common in the 1-2 year age group compared to the $<1$ year age group. ${ }^{8}$ However, after the 1 - 
2 year age group, diarrhea morbidity tended to decrease. Different research results can also be found in research conducted in Senegal. ${ }^{9}$ Cases of diarrhea in the study were more common in the 24-59 month age group than the $0-11$ and $12-23$ month age groups.

Age has an important influence in the case of diarrhea, because in general, the immune system of adults is better than that of children. ${ }^{5}$ The role of B cells in infants who are still not as good as older children and adults also affects the high cases of diarrhea in children aged less than 2 years old who have not been able to produce antibodies to the bacteria that cause diarrhea. ${ }^{10}$ Apart from the role of $B$ cells that have not been maximized, children aged 6-12 months old are more susceptible to diarrhea due to thinning maternal antibodies and contaminated complementary foods. ${ }^{11}$

In this study, it was found that diarrhea patients in children aged less than 5 years old were mostly male. The sex ratio of male and female sufferers in this study was 1.89: 1 . The results of this study have similar results with Indonesian Demographic and Health Survey (SDKI) and the 2013 Basic Health Research in which diarrhea sufferers are slightly higher in males. ${ }^{7}$ However, the ratio between the number of male and female sufferers in some of these studies is not so far when compared with this study. Similar results can also be found in the research of Maryanti, et al. ${ }^{6}$ Boys were $54.2 \%$ of the total sample in the study. Research conducted by Getachew, et al. (2018) gave a similar result with $59 \%$ of male suffered from diarrhea. ${ }^{8}$ In a study conducted by Yusuf (2011), differences in results were found in the sex distribution. ${ }^{5}$ Female children experienced a little more diarrhea, which was as much as $51.9 \%$. Several studies have consistent results in the distribution of sex, with differences in the number of sufferers that are not much different in male and female, although in this study there is a difference, where male patients outnumbered female patients significantly. Therefore, the effect of sex on the diarrhea morbidity of children still needs further research. In this study, more male affected by diarrhea could be caused by worse hygiene than girls and higher exposure to the outside world. ${ }^{12}$

It is found in this study that more patients were either undernourished or severely undernourished compared to patients with adequate nutrition or overly nourished. Among patients with malnutrition, diarrheal patients aged less than 5 years old found in Dr. Soetomo General Hospital were mostly severely undernourished, with 295 children (45.4\% of the total cases). The same results are found in a study in Bankura, India that found children under the age of 5 who were malnourished had a higher risk of diarrhea compared to children without malnutrition. ${ }^{13}$ The results of the research at Dr. Zainoel Abidin Hospital in Banda Aceh obtained slightly different results, where there were more diarrhea patients with adequate nourishment than those with undernutrition or malnutrition. ${ }^{5}$ Different research results from this study can also be found from research at the health center in Pekanbaru which provides results of diarrhea patients with adequate nutrition reaching
$94 \%$ of cases of diarrhea. ${ }^{6}$ Malnutrition in diarrhea can be either a cause or consequence of diarrhea morbidity. ${ }^{11,14}$ Malnutrition in children can cause atrophy in primary lymphoid organs, such as the thymus and bone marrow, thus in malnutrition there can be a lack of $B$ cell and $T$ cell production which makes children with malnutrition more susceptible to infectious diseases such as diarrhea. ${ }^{15}$ Malnutrition is an important factor in the case of diarrhea, although in several studies it was found that the incidence of diarrhea was slightly more common in sufferers without malnutrition.

According to WHO classification, diarrhea is a symptom of digestion which is characterized by increased frequency of defecation accompanied by liquid stool more than three times a day. Diarrhea is classified as acute watery diarrhea if it occurs less than 14 days, bloody diarrhea if blood is found in the feces, and persistent diarrhea if it occurs more than 14 days. ${ }^{1}$ In this study, the most frequent cases of acute watery diarrhea were found as many as $94.8 \%$, followed by $4.2 \%$ cases of persistent diarrhea, and other small portions of acute bloody diarrhea. The most frequent incidence of pediatric diarrhea in Dr. Zainoel Abidin Regional Hospital was acute diarrhea, followed by a small percentage of persistent diarrhea. ${ }^{5}$ In a study in Pekanbaru, no cases of bloody diarrhea were found. 6 About $3-20 \%$ of cases of acute diarrhea can develop into persistent diarrhea. Persistent diarrhea causes the risk of growth disturbance three times higher and death seven times higher than acute diarrhea. Persistent diarrhea is the cause of $23 \%-62 \%$ of deaths due to diarrhea. ${ }^{16}$

Dehydration is the loss of body fluids consisting of water and mineral salts. When children suffer from diarrhea, they will get a lot of loss of body fluids, thus they can become dehydrated. ${ }^{17}$ In this study, it was found that most diarrhea patients suffered mild-to-moderate dehydration, with 547 patients $(84.2 \%)$, followed by severe dehydration of 59 patients $(9.1 \%)$, and in the remaining small proportion of cases, the patients were not dehydrated. Children with diarrhea under 5 years old at Dr. Zainoel Abidin Regional Hospital Banda Aceh also experienced mild-to-moderate dehydration, but there were more sufferers without dehydration compared to severe dehydration. ${ }^{5}$ In the research conducted at Prof. Dr. RD Kandou Hospital Manado, acute diarrhea with severe dehydration was most common in boys under 1 year old $(60.5 \%)$. This may be caused by more exposure to the outside world and worse hygiene in men. ${ }^{12}$ The difference in results between studies by Manoppo (2017) and this study can be influenced by how quickly patients were taken to the hospital.

In this study, we found 542 (83.4\%) patients suffered from other diseases along with diarrhea. The diseases that accompanied the occurrence of diarrhea in this study were mostly in the form of severe undernourishment in 295 cases $(45.4 \%)$, followed by febrile seizures in 197 cases $(30.3 \%)$, malignancy in 93 cases (14.3\%), anemia as many as 67 cases (10.3\%), undernourishment as many as 61 
cases (9.4\%), and pneumonia as many as 53 cases $(8.2 \%)$. At Dr. Zainoel Abidin General Hospital Banda Aceh, 58\% of children with diarrhea had co-morbidity, malnutrition was the most common comorbid disease, followed by poor nutrition, bronchopneumonia, acute tonsillopharyngitis, complex febrile seizures, and varicella. The research in Banda Aceh gave slightly different results compared to this study, because in this study nutritional status was made a separate variable. In addition, this study found more febrile seizures and anemia compared with acute bronchopneumonia and tonsillopharyngitis. ${ }^{5}$ Co-morbidity of febrile seizures in patients with gastroenteritis was still not fully explained, but was thought to be related to the invasion of the virus that caused gastroenteritis to the central nervous system. On the electroencephalogram (EEG) examination of the patient, mild seizures were found, thus no antiepileptic therapy was needed. Seizures in diarrhea sufferers are more generalized, although focal seizures are also found. Seizure episodes in people with gastroenteritis can vary from 1-8 episodes in a 24-hour period. Seizures in patients with gastroenteritis are also more common in the 1-2 year age group without a history of epilepsy or seizures. Usually seizures are caused by Rotavirus, but it is usually afebrile. ${ }^{18,19}$ Diarrhea and acute lower respiratory tract infections are the highest causes of morbidity and mortality in children aged less than 5 years old. In children in India and Nepal, diarrhea and ARI occur together. Co-infection in children is more common, allegedly because the child's immune system is still immature. Several studies have found diarrhea and pneumonia often occur together. ${ }^{20}$ Anemia that occurs in many cases of diarrhea can also be associated with risk factors for diarrhea such as malnutrition. Malnutrition can cause bone marrow atrophy, thus it interferes with the process of hematopoiesis which then causes anemia. ${ }^{15}$

In the treatment of diarrhea in Dr. Soetomo General Hospital Surabaya, as many as 297 patients (45.7\%) were given antibiotic therapy. Giving antibiotics in diarrhea patients is usually done empirically in patients with complications, such as immunocompromised patients and patients with other comorbidities. Antibiotics can be given according to the cause. Diarrhea accompanied by fever, blood, leukocytes, lactoferrin, and syndrome of the minister can be given 3-5 days of quionolone therapy or cotrimoxazole 3-5 days. Patients with persistent diarrhea are advised to be given metronidazole $3 \times 500 \mathrm{mg}$ for 7 days for Giardiasis suspicion. Intestinal amoebiasis is treated with Metronidazole $3 \times 750 \mathrm{mg} \mathrm{5-10}$ days plus cyst treatment to prevent relapse or diiodohydroxyquin $3 \times 650$ $\mathrm{mg}$ for 10 days or paromomycin $3 \times 500 \mathrm{mg}$ for 10 days. In diarrhea that is suspected to be caused by Salmonella and Shigella, cotrimoxazole and quinolone can be used as treatment options. ${ }^{21}$ In patients at Dr. Soetomo General Hospital Surabaya, we found more patients treated with antibiotics than other hospitals because of the amount of patients with infection comorbidities was high, thus requiring antibiotic therapy.
Dehydration is a cause of mortality in pediatric diarrhea, so rehydration therapy is needed immediately for diarrhea sufferers. Patients with diarrhea in children under the age of 5 in the Children's Ward of Dr. Soetomo General Hospital Surabaya who received intravenous rehydration therapy were 648 people (99.7\%). Almost all diarrhea patients aged less than 14 years old at State General Hospital in Bali were also treated with intravenous rehydration, with details $93.48 \%$ of patients were given Ringer's Lactate and $13.04 \%$ of patients were given dextrose. ${ }^{22}$ In Dr. Soetomo General Hospital Surabaya, as many as $626(96.3 \%)$ patients with diarrhea in children aged less than 5 years old received probiotic therapy. Probiotics are bacteria which are the normal flora of the human intestine which have a positive effect if given orally. Probiotic therapy has proven its benefits in the treatment and prevention of diarrhea. Probiotics work by increasing the colonization of probiotic bacteria in the gastrointestinal lumen, thus all intestinal mucosal epithelium that has been occupied by probiotic bacteria can no longer be occupied by pathogenic bacteria, thereby preventing colonization of pathogenic bacteria. The mechanism of action of probiotics allows for prevention and treatment in patients with diarrhea caused by Rotavirus and other microbes, pseudomembranous colitis, and diarrhea due to irrational use of antibiotics. The use of probiotics in children is generally safe, but probiotic therapy in immunocompromised children needs to be closely monitored.23, 24 Zinc was given to 638 (98.2\%) diarrhea sufferers in children aged less than 5 years old who were hospitalized at Dr. Soetomo General Hospital Surabaya. Zinc is an essential micromineral that acts as an antioxidant that affects the absorption of water and sodium, prevents the disaccharidase enzyme deficiency, improves the immune system, and enzyme co-factors. In the case of diarrhea, WHO recommends giving zinc as diarrhea therapy to speed healing and prevent complications. ${ }^{25}$ Diarrhea therapy at Prof. Dr. RD Kandou Hospital Manado in general is the same as in Dr. Soetomo General Hospital Surabaya, however, there is a difference in the percentage of patients who received the therapy, such as giving zinc only covering $69 \%$, giving antibiotics covering $16 \%$, and giving probiotics only covering $12 \% .^{26}$

\section{Conclusion}

Based on the results of the research that has been done, the following is the profile of diarrhea sufferers in children aged less than 5 years old in the Children's Ward of Dr. Soetomo General Hospital Surabaya in 2016-2018:

1. Based on child factors, diarrhea was most common in boys, aged 6-11 months old, and severely undernourished.

2. Based on clinical characteristics, diarrhea was most often of acute watery diarrhea, mild-to-moderate degree of dehydration, accompanied by comorbidities, and the most common comorbidities were severe undernourishment. 
3. Based on the therapy given to the patients, most patients were treated with intravenous rehydration therapy.

\section{Acknowledgments}

1. Prof. Dr. Soetojo, dr., Sp.U(K) as the Dean of Faculty of Medicine, Universitas Airlangga.

2. Dr. Pudji Lestari, dr., M.Kes as the coordinator of research.

\section{CONFLICT OF INTEREST}

The author stated there is no conflict of interest in this study.

\section{REFERENCES}

1. Organization WH. Diarrhoeal Disease. Geneva: World Health Organization, 2017.

2. Indonesia KKR. Riset Kesehatan Dasar. Jakarta: Kementerian Kesehatan Republik Indonesia, 2013.

3. Indonesia KKR. Buletin Jendela Data dan Informasi Kesehatan: Situasi Diare di Indonesia. In: Informasi PDd, (ed.). Jakarta: Kementerian Kesehatan Republik Indonesia, 2011.

4. Soenarto $Y$, Supardi $S$ and Suryono A. Dysentry in Children Under Five Year of Age: A Longitudinal Prospective Study in Primary Health Care in Indonesia. Paediatrica Indonesiana. 2001: 141-8.

5. Yusuf S. Profil Diare di Ruang Rawat Inap Anak. Sari Pediatri. 2016; 13: 265

6. Maryanti E, Lesmana S, Mandela H and Herlina S. Profil Penderita Diare Anak di Puskesmas Rawat Inap Pekanbaru. Jurnal Ilmu Kedokteran. 2017; 8: 101.

7. Depkes R. Profil Data Kesehatan Indonesia Tahun 2011. Kementerian Kesehatan Republik Indonesia. 2011.

8. Getachew A, Guadu T, Sewhulu A, et al. Diarrhea Prevalence and Sociodemographic Factors among UnderFive Children in Rural Areas of North Gondar Zone, Northwest Ethiopia. International Journal of Pediatrics. 2018; 2018: 1-8.

9. Thiam S, Diène AN, Fuhrimann $S$, et al. Prevalence of Diarrhoea and Risk Factors among Children under Five Years Old in Mbour, Senegal: A Cross-Sectional Study. Infect Dis Poverty. 2017; 6: 109.

10. Harsono A. Immunomodulatory Effects of Human Milk upon Immune Functions in Infants. Indonesian Pediatric Society, 1999.

11. Baqui $\mathrm{AH}$ and Ahmed T. Diarrhoea and Malnutrition in Children. BMJ (Clinical research ed). 2006; 332: 378.
12. Manoppo J. Profil Diare Akut dengan Dehidrasi Berat di Ruang Perawatan Intensif Anak. Sari Pediatri. 2016; 12 : 157.

13. Gupta A, Sarker G, Rout AJ, Mondal T and Pal R. Risk Correlates of Diarrhea in Children under 5 Years of Age in Slums of Bankura, West Bengal. Journal of Global Infectious Diseases. 2015; 7: 23-9.

14. Schaudecker EP, Steinhoff MC and Moore SR. Interactins of Diarrhea, Pneumonia, and Malnutrition in Childhood: Recent Evidence from Developing Countries. Current Opinion in Infectious Diseases. 2011; 24: 496-502. 15. França $\mathrm{T}$, Ishikawa $\mathrm{L}$, Zorzella-Pezavento SFG, Chiuso-Minicucci F, Ribeiro de Souza da Cunha MdL and Sartori A. Impact of Malnutrition on Immunity and Infection. Journal of Venomous Animals and Toxins Including Tropical Diseases - J Venom Anim Toxins Trop Dis. 2009; 15.

16. Putra IGN, Firmansyah A, Hegar B, Boediarso A, Kadim $\mathrm{M}$ and Alatas FS. Faktor Risiko Diare Persisten pada Pasien yang Dirawat di Departemen IImu Kesehatan Anak RS Dr. Cipto Mangunkusumo Jakarta. Sari Pediatri. 2016; 10: 42 .

17. Society CP. Dehydration and Diarrhea. Paediatrics \& Child Health. 2003; 8: 459-60.

18. Kang B and Kwon YS. Benign Convulsion with Mild Gastroenteritis. Korean Journal of Pediatrics. 2014; 57: 304-9.

19. Khalesi M, Heydarian F, Sayedi SJ, Badzai S and Heidari E. Convulsion Associated with Gastroenteritis. Reviews in Clinical Medicine. 2018; 5: 115-7.

20. Walker CL, Perin J, Katz J, Tielsch JM and Black RE. Diarrhea as a Risk Factor for Acute Lower Respiratory Tract Infections among Young Children in Low Income Settings. Journal of Global Health. 2013; 3: 010402.

21. Amin LZ. Tatalaksana Diare Akut. 2015.

22. Siswidiasari A. Profil Terapi Obat pada Pasien Rawat Inap dengan Diare Akut pada Anak di Rumah Sakit Umum Negara. Journal of Chemistry, 2015.

23. Firmansyah A. Terapi Probiotik dan Prebiotik pada Penyakit Saluran Cerna Anak. Badan Penerbit Ikatan Dokter Anak Indonesia (BP-IDAI), 2016.

24. Sudarmo S, Ranuh R, Djupri L and Soeparto P. Managemen Diare pada Bayi dan Anak. Buku Kuliah IImu Kesehatan Anak. Surabaya: Divisi Gastroenterologi Lab/SMF IImu Kesehatan Anak Fakultas Kedokteran Universitas Airlangga/RSU Dr. Soetomo Surabaya, 2007. 25. Artana W, Suraatmaja S, Aryasa K and Suandi IKG. Peran Suplementasi Mineral Mikro Seng Terhadap Kesembuhan Diare. Sari Pediatri. 2016; 7: 15.

26. Korompis F, Tjitrosantoso $\mathrm{H}$ and Goenawi LR. Studi Penggunaan Obat pada Penderita Diare Akut di Instalasi Rawat Inap BLU RSUP Prof. Dr. R. D. Kandou Manado Periode Januari - Juni 2012. 2013. 2013; 2. 